See discussions, stats, and author profiles for this publication at: https://www.researchgate.net/publication/297722491

\title{
Repeated detection of an Invertebrate Iridovirus (IIV) in Amphibians
}

Article $\cdot$ March 2016

DOI: 10.5818/15-03-041.1

CITATIONS

2

3 authors:

Anke C Stöhr

Louisiana State University

30 PUBLICATIONS 220 CITATIONS

SEE PROFILE

(2) Rachel E Marschang

(4) Laboklin $\mathrm{GmbH}$

350 PUBLICATIONS 1,671 CITATIONS

SEE PROFILE

Some of the authors of this publication are also working on these related projects:

Project Reptile paramyxoviruses View project

Project Identification and characterization of replilian and amphibian ranaviruses detected in Portugal View project

\section{READS}

176

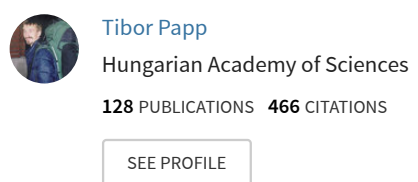




\section{Repeated Detection of an Invertebrate Iridovirus (IIV) in Amphibians}

2

3 Anke C. Stöhr ${ }^{1}$, med. vet., Tibor Papp ${ }^{2}$, DVM, MSc zoology, PhD, Rachel E. Marschang ${ }^{1,3}$,

4 PD Dr. med. vet., DECZM (Herpetology), FTÄ Mikrobiologie, ZB Reptilien ${ }^{\text {a,c }}$ 5

6

$7 \quad{ }^{1}$ Fachgebiet für Umwelt- und Tierhygiene, Universität Hohenheim, Garbenstr. 30, 70599

$8 \quad$ Stuttgart, Germany

$9 \quad{ }^{2}$ Institute for Veterinary Medical Research, Centre for Agricultural Research of the Hungarian

10 Academy of Science, H-1143 Budapest, Hungária krt. 21, Hungary

$11{ }^{3}$ Laboklin GmbH \& Co. KG, Laboratory for Clinical Diagnostics, Steubenstr. 4, 97688 Bad

12 Kissingen, Germany

13

$14{ }^{*}$ Corresponding author. Tel.: +49 (0)971 72020 Fax: +49 (0)971 68546

15 E-mail address: rachel.marschang@googlemail.com

16 Address: Dr. Rachel E. Marschang, Laboklin GmbH \& Co. KG, Laboratory for Clinical

17 Diagnostics, Steubenstr. 4, 97688 Bad Kissingen, Germany 


\section{Abstract}

19 Invertebrate iridoviruses (IIVs) (family: Iridoviridae) are known pathogens for invertebrates, 20 causing high mortality and reduced fertility in affected insects. Over the past 2 decades, IIVs 21 have also been increasingly found in lizards in association with nonspecific clinical signs. It 22 has been hypothesized that IIVs from insects can also infect reptiles. From 2010-2011, IIVs 23 were repeatedly detected via polymerase chain reaction testing and virus isolation methods in 24 routine diagnostic samples from different amphibians: 3 blue poison dart frogs (Dendrobates 25 tinctorius azureus), 4 edible frogs (Pelophylax kl. esculentus), a giant ditch frog 26 (Leptodactylus fallax), an Amazon milk frog (Trachycephalus resinifictrix), mixed organs 27 from agile frogs (Rana dalmatina), a black-spined toad (Bufo melanostictus), and one Lake

28 Urmia newt (Neurergus crocatus). IIVs were found in skin swabs from apparently healthy 29 animals, as well as in multiple organs of frogs that died of unknown causes. Prey insects 30 (crickets) from one owner also tested positive for the presence of IIV. The obtained partial 31 sequences from the major capsid protein (MCP) gene (222nt) from each of these were $100 \%$ 32 identical to each other and 98\% identical to IIV-6, the type species of the genus Iridovirus. 33 Although the pathogenicity of IIV in amphibians remains unclear, these findings provide 34 further evidence that IIVs may be able to infect vertebrates under some conditions and 35 underline the importance of the genus Iridovirus in vertebrates.

37 Keywords: anuran, frog, Invertebrate Iridovirus 6, newt, urodele, cricket 
Introduction

39 Iridoviruses are large double-stranded, cytoplasmic DNA viruses. The family Iridoviridae

40 consists of five recognized genera, which are important pathogens for ectothermic vertebrates

41 (genera: Lymphocystivirus, Megalocytivirus, Ranavirus) and insects (genera: Iridovirus,

42 Chloriridovirus) (Jancovich et al., 2012). Another group of closely related viruses with a

43 predilection for red blood cells, Erythrocytic iridoviruses (EIVs), have been found in

44 squamates, fish, and amphibians. Phylogenetic investigations on squamate EIVs indicate that 45 these viruses may represent a novel iridovirus genus (Wellehan et al., 2008; Alves de Matos 46 et al., 2011).

47

To date, the genus Iridovirus comprises two species: Invertebrate iridescent virus 1 (IIV-1, syn. Tipula iridescent virus [TIV]) and Invertebrate iridescent virus 6 (IIV-6, syn. Chilo iridescent virus [CIV]), as well as numerous unclassified isolates. Confirmed or putative

51 infections with invertebrate iridoviruses (IIVs) have been reported in more than 100 species

52 of invertebrates from various habitats on all continents except Antarctica. The infection causes lethal disease in susceptible insects manifested by hypertrophy and bluish iridescence of the affected fat body cells arising from the quasicrystalline arrangement of virus particles in the host cells. However, covert sublethal infections were reported in several host species and may have reduced the former interest in their potential use for controlling important

57 agricultural pest and vector insect species (Williams, 2008).

59 Cricket iridovirus (CrIV), a variant of IIV-6, was identified as the causative agent for unusual 60 mortalities and reduced fertility and lifespan in diseased animals (field crickets [Gryllus 61 campestris], house crickets [Acheta domesticus]) from a commercial cricket producer in the 62 Netherlands (Kleespies et al., 1999; Jakob et al., 2002). Another closely related iridovirus 
63 (Gryllus bimaculatus iridovirus [GbIV]) has been detected in crickets from a breeder of field 64 crickets (Gryllus bimaculatus) in Germany (Just and Essbauer, 2001). Investigation on the

65 host range of CrIV demonstrated that the virus can be transmitted orally to other orthopteran 66 species, reflecting a considerable problem for commercial insect breeders.

67

68 Since 1998, IIVs have also been repeatedly detected in reptilian hosts including bearded 69 dragons (Pogona vitticeps), a four-horned chameleon (Chamaeleo quadricornis), a high70 casqued chameleon (Chamaeleo hoehnelii), a frilled lizard (Chlamydosaurus kingii), green 71 striped tree dragons (Japalura splendida), an Asian glass lizard (Dopasia gracilis), and a 72 green anole (Anolis carolinensis) (Just et al., 2001; Weinmann et al., 2007; Behncke et al., 73 2013; Stöhr et al., 2013a), as well as in numerous other insectivorous lizards (authors 74 unpublished observations; Papp et al., 2014).The IIV detected in the high-casqued chameleon 75 was $100 \%$ identical to GbIV on partial sequences of the major capsid protein (MCP) gene. It 76 has therefore been hypothesized that IIV from prey insects might be transmitted to reptiles. 77 Over a period of two years (2010-2011), IIVs were repeatedly detected in diagnostic samples 78 from amphibians. This paper describes these cases from different amphibian species and the 79 partial characterization of the isolated viruses.

\section{Materials and Methods}

\section{Samples}

83 Samples from apparently healthy, quarantined animals, as well as from dead amphibians were 84 submitted for virological testing. The different samples (skin swabs / organs) were obtained 85 from blue poison dart frogs (Dendrobates tinctorius azureus) $(\mathrm{n}=4)$, edible frogs (Pelophylax 86 kl. esculentus) $(\mathrm{n}=4)$, a giant ditch frog (Leptodactylus fallax), an Amazon milk frog 87 (Trachycephalus resinifictrix), agile frogs (Rana dalmatina) (n=6), a black-spined toad (Bufo 
melanostictus), and Lake Urmia newts (Neurergus crocatus) (n=3). Prey insects (crickets) from one owner were also submitted for virological examination. Short case histories and a list of tested samples are given in Table 1. No samples were available for histopathological examination.

\section{Virological testing}

Samples were taken from each animal separately and submitted in cell culture medium (Dulbecco’s modified Eagle medium (DMEM), Biochrom AG, Berlin, Germany) supplemented with antibiotics. The samples were sonified, centrifuged at low speed, and inoculated onto iguana heart cells (IgH-2, ATCC: CCL-108) for virus isolation as described previously (Stöhr et al., 2013b). DNA was extracted from the original sample or from the cell culture supernatant using a commercial DNA extraction kit (DNeasy Kit ${ }^{\circledR}$, Qiagen GmbH, Hilden, Germany), and routine diagnostic polymerase chain reactions (PCRs) for the detection of IIV targeting a part of the MCP gene were done as described previously (Weinmann et al., 2007). All samples were also tested for the presence of ranaviruses (Mao et al., 1997; Marschang et al., 1999). The obtained PCR products were separated by agarose gel electrophoresis (1.5\% agarose gel; Biozym Scientific GmbH, Hessisch Oldendorf, Germany) in TAE buffer containing $0.5 \mu \mathrm{g} / \mathrm{mL}$ ethidium-bromide and visualized under $320 \mathrm{~nm} \mathrm{UV}$ light. Afterwards, the PCR amplicons were cut and gel purified using a gel extraction kit (peqGOLD Gel Extraction Kit ${ }^{\circledR}$, Peqlab Biotechnologie GmbH, Erlangen, Germany) and sent for sequencing from both directions to a commercial company (MWG Biotech AG, Ebersberg, Germany). Obtained sequences were edited, assembled, and compared using STADEN Package version 2003.0 Pregap4 and Gap4 programmes (Bonfield et al., 1995). Finally, the sequences were compared to those in GenBank (National Center for Biotechnology Information, Bethesda, MD) online (http://www.ncbi.nih.gov/blast/) using 
113 BLASTN option and to the local iridovirus database of the Fachgebiet für Umwelt- und

114 Tierhygiene at Hohenheim University.

115

116 Results

117 IIVs were found in at least 12 animals belonging to 7 amphibian species from 5 collections

118 (Table 1). In some cases, IIVs were found in skin swabs from apparently healthy animals.

119 Other animals died and IIVs were detected in different organs from these animals; one of

120 these animals, a Lake Urmia newt, was coinfected with a ranavirus. Crickets collected from

121 one owner also tested positive for the presence of IIV. The partial sequences from the MCP

122 genes (222nt) of all detected IIVs were $100 \%$ identical to each other and $98 \%$ identical to IIV-

1236 , the type species of the genus Iridovirus (AF303741), as well as $100 \%$ identical to CIV and

$124 \mathrm{GbIV}$, which have been previously found in crickets and lizards (Kleespies et al., 1999; Just

125 and Essbauer, 2001; Just et al., 2001).

126

\section{Discussion}

128 This is the first description of IIVs in amphibians. Unfortunately, little is known about the

129 impact of these pathogens in vertebrates. Clinical signs observed in lizards infected with IIVs

130 have been relatively non-specific and included poor body condition, skin lesions, pneumonia,

131 hyperemic liver, and enlarged spleen (Just et al., 2001; Weinmann et al., 2007; Papp et al.,

132 2014). Recently, coinfections of IIVs with other viruses (ranavirus and/or adenovirus) have

133 been described in a number of severely diseased lizards with various clinical signs, as well as

134 skin alterations (Behncke et al., 2013; Stöhr et al., 2013a). In these animals, IIVs have been

135 found in the skin of Asian glass lizards, green anoles, and in the skin and internal organs of

136 dead green striped tree dragons. Ranaviruses - which are known pathogens for ectothermic

137 vertebrates - were also found in these samples and were considered to be one of the causative 
138 agents for the disease. Interestingly, IIVs were also detected in the skin (swabs/tissue

139 samples) from 8 amphibians in this study. However, the severe course of disease observed in

140 the Lake Urmia newts was most likely caused by a ranaviral infection. IIVs are relatively

141 commonly found in oral or cloacal swabs from insectivorous lizards (authors unpublished

142 observations); however, it is unclear whether the virus replicates in these animals or if the

143 viruses detected only passed through the animals via ingestion of infected prey insects. The

144 interpretation of the presence of IIV in samples from the skin or the gastrointestinal tract in

145 amphibians poses the same problem of possible environmental contamination from infected

146 prey sources. However, the fact that IIV was found in samples from internal nondigestive

147 organs during this study clearly indicates that these animals were infected with the virus: IIV

148 was detected in pooled samples (liver and kidney) from agile frogs and in the kidney from an

149 edible frog which died of unknown causes during hibernation. The edible frog was the only

150 animal in which macroscopic pathological changes were found in the tested tissue sample

151 (reddening of the kidneys) and no other virus was detected. Nevertheless, these results have to

152 be interpreted with caution, as no histopathological examination was carried out; this could

153 have helped confirm virus-related tissue alterations in these organs. Virus detection in tissue

154 extracts by PCR or cell culture could also reflect the presence of virus in the blood (either in

155 the plasma or in the cell component or both) and not necessarily in the tissue parenchyma

156 itself. No clinical signs were observed in the prey insects submitted by one of the owners,

157 which tested positive for the presence of IIV, and sequencing results indicated that the same

158 virus was found in all tested animals.

160 A number of viruses affecting lower vertebrates are known to have a wide host range, but the

161 diversity of host specificity patterns is still poorly understood (Bandin and Dopazo, 2011).

162 However, the ability of large DNA viruses to replicate completely in the cytoplasm seems to 
163 be strongly connected with an increased ability to jump hosts, compared to those with

164 intranuclear replication (Pulliam and Dushoff, 2009). Field data, experimental trials, and

165 genomic studies have demonstrated that members of the family Iridoviridae (genus:

166 Ranavirus) are capable of infecting hosts from different poikilothermic classes (Duffus et al.,

167 2015). Ranaviruses have also been found in invertebrates, and mosquitoes may be a possible

168 vector for ranavirus transmission to terrestrial turtles (Kimble et al., 2014). Previous studies

169 provided evidence that highly infected but clinically healthy insects might infect insectivorous

170 reptiles with IIV (Weinmann et al., 2007). In per os infection trials with bearded dragons,

171 IIVs were also detected in nondigestive organs (Papp, 2014). It is therefore possible that the

172 amphibians in our study were infected by the crickets fed to them.

173

174 Investigations on ranaviruses have demonstrated that the MCP gene may not be a suitable

175 target to distinguish different virus strains and that comparison of partial sequences may show

176 viruses to be more closely related than they actually are (Duffus and Andrews, 2013). Since

177 the MCP gene in IIVs is also highly conserved, and only a small portion has been sequenced,

178 it is possible that the isolates detected in this study may also differ from each other.

179 Sequencing of the complete MCP gene, or other more variable regions, would be useful to

180 learn more about the isolated viruses.

181

182 Interspecies transmission has been demonstrated for different IIVs (Williams et al., 2005),

183 and a GbIV isolated from a high-casqued chameleon has been shown to be pathogenic for

184 crickets (Gryllus bimaculatus) (Weinmann et al., 2007). Experimental infection trials with

185 amphibians supported by virological methods (e.g., electron microscopy of internal organs for

186 the detection of iridoviral virions in infected tissue, in situ hybridization to determine

187 invertebrate iridovirus infection in vertebrate cells, or the use of reverse transcriptase [RT] 
PCR to prove virus replication) should be considered in future studies to determine if IIV is

189 able to cause disease in amphibians. Furthermore, histopathological investigations of affected

190 tissues (skin and internal organs) from animals with and without apparent clinical signs would

191 help to elucidate ongoing changes at the cellular level consistent with viral infections.

192 Although the pathogenicity of IIV in amphibians remains unclear, the detection of IIV in

193 amphibians provides further evidence that these viruses may be able to infect vertebrate hosts

194 under some circumstances and underlines the importance of the genus Iridovirus in

195 vertebrates.

196

197 Acknowledgements

198 We are grateful to Christa Schäfer for her help in the laboratory in Hohenheim and to the 199 submitting veterinarians for providing samples and background information on the cases.

\section{Declaration of conflicting interest}

202 The authors declared no potential conflicts of interest with respect to the research, authorship, or publication of this article. REM is employed by a private lab (Laboklin) that offers

204 diagnostic services for veterinarians. This employment did not influence study design, 205 interpretation, or publication preparation.

207 Fundings

208 The authors received no financial support for the research, authorship, or publication of this 209 article.

210

\section{$211 \quad$ Literature Cited}


212 1. Alves de Matos AP, Caeiro MF, Papp T, Matos BA, Correia AC, Marschang RE. 2011.

213 New viruses from Lacerta monticola (Serra da Estrela, Portugal): further evidence for a new

214 group of nucleo-cytoplasmic large deoxyriboviruses. Microsc Microanal 17(1):101-108.

215 2. Bandin I, Dopazo CP. 2011. Host range host specificity and hypothesized host shift events

216 among viruses of lower vertebrates. Vet Res 42:67.

217 3. Behncke H, Stöhr AC, Heckers K, Ball I, Marschang RE. 2013. Mass-mortality in green

218 striped tree dragons (Japalura splendida) associated with multiple viral infections. Vet Rec

219 173(10):248.

220 4. Bonfield JK, Smith KF, Staden R. 1995. A new DNA sequence assembly program. Nucleic 221 Acids Res 23(24):4992-4999.

222 5. Duffus ALJ, Andrews AM. 2013. Phylogenetic analysis of a frog virus 3-like ranavirus

223 found at a site with recurrent mortality and morbidity events in southeastern Ontario, Canada:

224 partial major capsid protein sequence alone is not sufficient for fine-scale differentiation. J

225 Wildl Dis 49:464-467.

226 6. Duffus ALJ, Waltzek TB, Stöhr AC, Allender MC, Gotesman M, Whittington RJ, Hick P, 227 Hines MK, Marschang RE. 2015. Distribution and host range of ranaviruses. In Gray MJ, 228 Chinchar VG (eds): Ranaviruses: Lethal pathogens of ectothermic vertebrates, Springer, New 229 York: 9-58.

230 7. Jancovich JK, Chinchar VG, Hyatt A, Miyazaki T, Williams T, Zhang QY. 2012. Family

231 Iridoviridae. In King AMQ, Adams MJ, Carstens EB, Lefkowitz EB (eds): Family

232 Iridoviridae, Virus Taxonomy: 9th Report of the ICTV, Elsevier, San Diego, CA:93-210.

233 8. Jakob NJ, Müller K, Bahr U, Darai G. 2002. Comparative analysis of the genome and host

234 range characteristics of two insect iridoviruses: Chilo iridescent virus and a cricket iridovirus 235 isolate. J Gen Virol 83:463-470. 
9. Just F, Essbauer S, Ahne W, Blahak S. 2001. Occurrence of an invertebrate iridescent-like

237 virus (Iridoviridae) in reptiles. J Vet Med B Infect Dis Vet Public Health 48:685-694.

238 10. Just FT, Essbauer SS. 2001. Characterization of an iridescent virus isolated from Gryllus

239 bimaculatus (Orthoptera: Gryllidae). J Invertebr Pathol 77 (1):51-61.

240 11. Kimble SJA, Karna AK, Johnson AJ, Hoverman JT, Williams RN. 2014. Mosquitoes as a

241 potential vector of ranavirus transmission in terrestrial turtles. EcoHealth.

242 doi:10.1007/s10393-014-0974-3

243 12. Kleespies R, Tidona C, Darai G. 1999. Characterization of a new iridovirus isolated from

244 crickets and investigations on the host range. J Invertebr Pathol 73(1):84-90.

245 13. Mao J, Hedrick RP, Chinchar VG. 1997. Molecular characterization, sequence analysis,

246 and taxonomic position of newly isolated fish iridoviruses. Virology 229(1):212-220.

247 14. Marschang RE, Becher P, Posthaus H, Wild P, Thiel H-J, Müller-Doblies U, Kaleta EF,

248 Bacciarini LN. 1999. Isolation and characterization of an iridovirus from Hermann's tortoises

249 (Testudo hermanni). Arch Virol 144(10):1909-1922.

250 15. Papp T, Spann D, Marschang RE. 2014. Development and use of a real-time PCR for the 251 detection of group II invertebrate iridoviruses in pet lizards and prey insects. J Zoo Wildl Med $252 \quad 45(2): 219-227$.

253 16. Papp T. 2014. Detection and characterisation of adeno-, irido- and paramyxoviruses in 254 reptiles. PhD Dissertation, 2012. Szent István Univ., Gödöllő, Hungary, Available at:

255 http://huveta.hu/bitstream/10832/866/1/PappT-D-E.pdf

256 17. Pulliam J, Dushoff J. 2009. Ability to replicate in the cytoplasm predicts zoonotic

257 transmission of livestock viruses. J Infect Dis. 199:565-568.

258 18. Stöhr AC, Blahak S, Heckers KO, Wiechert J, Behncke H, Mathes K, Günther P, Zwart P,

259 Ball I, Rüschoff B, Marschang RE. 2013a. Ranavirus infections associated with skin lesions

260 in lizards. Vet Res 44:84. 
261 19. Stöhr AC, Hoffmann A, Papp T, Robert N, Pruvost NBM, Reyer H-U, Marschang RE.

262 2013b. Long-term study of an infection with ranaviruses in a group of edible frogs

263 (Pelophylax kl. esculentus) and partial characterization of two viruses based on four genomic

264 regions. Vet J 197(2):238-244.

265 20. Stöhr AC, Fleck J, Mutschmann F, Marschang RE. 2013c. Ranavirus infection in a group

266 of wild-caught Lake Urmia newts (Neurergus crocatus) imported from Iraq into Germany.

267 Dis Aquat Organ 103(3):185-189.

268 21. Weinmann N, Papp T, Alves de Matos AP, Teifke JP, Marschang RE. 2007. Experimental

269 infection of crickets (Gryllus bimaculatus) with an invertebrate iridovirus isolated from a

270 high-casqued chameleon (Chamaeleo hoehnelii). J Vet Diagn Invest 19:674-679.

271 22. Wellehan JFX, Strik NI, Stacy BA, Childress AL, Jacobsen ER, Telford SR. 2008.

272 Characterization of an erythrocytic virus in the family Iridoviridae from a peninsula ribbon

273 snake (Thamnophis sauritus sackenii). Vet Microbiol 131(1-2):115-122.

274 23. Williams T. 2008. Natural invertebrate hosts of iridoviruses (Iridoviridae). Neotrop

275 Entomol 37(6):615-632.

276 24. Williams T, Barbosa-Solomieu V, Chinchar VG. 2005. A decade of advances in iridovirus

277 research. Adv Virus Res 65:173-248.

278 
279 Table 1: Samples from the different amphibian species included in this report with short case

280 histories, the results of virus isolation on cell culture (IgH-2), and the PCR for the presence of

281 invertebrate iridovirus (IIV) and ranavirus.

\begin{tabular}{|c|c|c|c|c|c|c|}
\hline $\begin{array}{l}\text { Date of } \\
\text { testing }\end{array}$ & Species & Case history & Samples & $\begin{array}{l}\text { IIV } \\
\text { isolation in } \\
\text { cell culture }\end{array}$ & $\begin{array}{l}\text { IIV PCR } \\
\text { from } \\
\text { original } \\
\text { sample } \\
\end{array}$ & $\begin{array}{l}\text { Detection } \\
\text { of ranavius }\end{array}$ \\
\hline $09 / 2010$ & $\begin{array}{c}\text { Blue poison dart } \\
\text { frogs } \\
\text { (Dendrobates } \\
\text { tinctorius azureus) }\end{array}$ & $\begin{array}{l}\text { Apparently healthy } \\
\text { animals from a zoo in } \\
\text { Switzerland. Newly } \\
\text { obtained from a private } \\
\text { breeder, in quarantine. }\end{array}$ & $\begin{array}{c}\text { Skin swabs } \\
\text { from } 4 \text { animals }\end{array}$ & 3 positive & 3 postive & negative \\
\hline $03 / 2011$ & $\begin{array}{l}\text { Edible frogs } \\
\text { (Pelophylax kl. } \\
\text { esculentus) }\end{array}$ & $\begin{array}{l}\text { Group of animals from } \\
\text { various European ponds } \\
\text { infected with } \\
\text { ranaviruses. Dead + } \\
\text { apparently healthy } \\
\text { animals tested for virus } \\
\text { shedding over a period of } \\
3 \text { years (Stöhr et al., } \\
2013 b \text { ). } \\
\text { Animal died during } \\
\text { hibernation, reddening of } \\
\text { the kidneys. }\end{array}$ & $\begin{array}{l}\text { Kidney, liver, } \\
\text { skin }\end{array}$ & $\begin{array}{l}\text { positive } \\
\text { (kidney) }\end{array}$ & negative & negative \\
\hline $04 / 2011$ & & $\begin{array}{l}\text { See above - clinically } \\
\text { healthy animals. }\end{array}$ & $\begin{array}{l}\text { Skin swabs } \\
\text { from } 30 \text { animals }\end{array}$ & 3 positive & 2 positive & negative \\
\hline $07 / 2011$ & $\begin{array}{l}\text { Lake Urmia newts } \\
\text { (Neurergus } \\
\text { crocatus) }\end{array}$ & $\begin{array}{l}\text { Group of animals } \\
\text { imported from Iraq in } \\
\text { April } 2011.10 / 11 \\
\text { animals died due to } \\
\text { ranaviral infection. } \\
\text { Clinical signs: anorexia, } \\
\text { apathy, ulcerative } \\
\text { dermatitis, systemic } \\
\text { haemorrhages, } \\
\text { granulomatous } \\
\text { hepatitis (Stöhr et al., } \\
\text { 2013c). }\end{array}$ & $\begin{array}{l}\text { Skin }+ \text { mixed } \\
\text { organs (liver, } \\
\text { kidney) from } 3 \\
\text { animals }\end{array}$ & $\begin{array}{l}1 \text { positive } \\
\text { (skin) }\end{array}$ & negative & $\begin{array}{l}\text { via PCR in } \\
\text { this and } \\
\text { one other } \\
\text { animal } \\
\text { (skin }+ \\
\text { organs) }\end{array}$ \\
\hline \multirow[t]{2}{*}{$07 / 2011$} & \multirow{2}{*}{$\begin{array}{c}\text { Giant Ditch Frog } \\
\text { (Leptodactylus } \\
\text { fallax) }\end{array}$} & \multirow{4}{*}{$\begin{array}{l}\text { Deaths of several } \\
\text { amphibians in a } \\
\text { zoological institution in } \\
\text { the United Kingdom }\end{array}$} & $\begin{array}{l}\text { Frozen large } \\
\text { intestine wall } \\
\text { lesion }\end{array}$ & positive & positive & negative \\
\hline & & & $\begin{array}{l}\text { Frozen large } \\
\text { intestine mass }\end{array}$ & positive & positive & negative \\
\hline $07 / 2011$ & $\begin{array}{l}\text { Amazon milk frog } \\
\text { (Trachycephalus } \\
\text { resinifictrix) }\end{array}$ & & $\begin{array}{l}\text { Frozen pyloric } \\
\text { nodule }\end{array}$ & negative & positive & negative \\
\hline $07 / 2011$ & $\begin{array}{c}\text { Agile frogs } \\
\text { (Rana dalmatina) }\end{array}$ & & $\begin{array}{l}\text { Frozen mixed } \\
\text { organs (liver, } \\
\text { kidneys) from } \\
\text { six animals } \\
\end{array}$ & negative & positive & negative \\
\hline
\end{tabular}




\begin{tabular}{|c|l|l|l|l|l|l|}
\hline & & & $\begin{array}{l}\text { Frozen skin } \\
\text { from six } \\
\text { animals }\end{array}$ & negative & negative & negative \\
\hline $09 / 2011$ & Crickets & $\begin{array}{l}\text { Prey animals from the } \\
\text { zoological institution in } \\
\text { the United Kingdom }\end{array}$ & $\begin{array}{l}\text { Animals (fat } \\
\text { bodies) }\end{array}$ & positive & not done & not done \\
\hline $\begin{array}{c}\text { (Bufo } \\
\text { melanostictus) }\end{array}$ & $\begin{array}{l}\text { Temporary housing in a } \\
\text { reptile rescue center in } \\
\text { Germany, no clinical } \\
\text { signs. }\end{array}$ & Skin swab & positive & positive & negative \\
\hline
\end{tabular}

282 